\title{
THE AEROGEOPHYSICAL PROJECT SERRA DO MAR SUL IN THE REGION OF THE CUNHAPORANGA GRANITIC COMPLEX, PARANÁ, SOUTHERN BRAZIL: ANALYSIS OF THE GAMMA-RAY SPECTROMETRIC SURVEY.
}

\author{
Gilson B. Guimarães ${ }^{1}$, Francisco J. F. Ferreira ${ }^{2}$, Horstpeter H. G. J. Ulbrich ${ }^{3}$ \\ \& Maximilian Forlin ${ }^{2}$
}

Received January 22, 2000 / Accepted August 25, 2002

\begin{abstract}
This paper analyses sprectrometric data of the Aerogeophysical Project Serra do Mar Sul (APSMS) in the Meso to Neoproterozoic basement of eastern Paraná state, southern Brazil. Three main lithostratigraphic units are found, elongated N30-40E. The easternmost is the Três Córregos Granitic Complex (TCGC), constituted by calcalkaline granites and their mega-enclaves. The central unit is the low-grade metamorphic Itaiacoca Group. The western strip is occupied by the mostly calc-alkaline Cunhaporanga Granitic Complex (CGC), also with large enclaves. Further west, the molassic volcano-sedimentary Eopaleozoic Castro Group, deposited in a graben, overlies unconformably the CGC. The Devonian sandstone Furnas Formation, to the west, is the main unit of the Paraná Basin in this region. The Cretaceous Banhadão alkaline massif $\left(8 \mathrm{~km}^{2}\right)$ intrudes the TCGC. The heavily weathered central-northern area of the CGC is in part covered by the alluvial deposits of the Iapó drainage basin. Data were corrected with a cosine directional filter (degree 6), and presented as cps (counts per second). $\mathrm{U}$ and $\mathrm{K}$ give answers that may be spurious, not always correlated with the geology. Most CGC intrusions present rather high Th-U, lower total (TC) and very low K counts, as opposed to the values found in the TCGC. High TC are found in some of the more evolved plutons within the CGC (e.g., the A-type Serra do Carambei Granite). The TCGC granites can be divided into two radiometric domains, one adjacent to the Itaiacoca belt and another to the E-SE (visible in TC and K counts), corresponding to the São Sebastião Granite. The mega-enclaves show lower counts in all channels than the surrounding granites. The Itaiacoca belt is marked in TC and U-Th maps by low to medium counts. The Castro Group shows a complex pattern controlled by lithology. The Furnas sediments show low to medium responses (TC map). The Iapó river deposits stand out clearly by very low counts (TC, U, Th) against the CGC rocks.
\end{abstract}

Key words: Airborne gamma-ray survey; Geological mapping; Aerogeophysical Project Serra do Mar Sul; Cunhaporanga and Três Córregos Granitic Complexes.

O PROJETO AEROGEOFÍSICO SERRA DO MAR SUL NA REGIÃO DO COMPLEXO GRANÍTICO CUNHAPORANGA, PARANÁ: ANALISE DO LEVANTAMENTO GAMAESPECTROMÉTRICO - Este trabalho analisa dados gamaespectrométricos do Projeto Aerogeofísico Serra do Mar Sul no embasamento meso a neoproterozóico, leste do estado do Paraná, Brasil meridional. Três unidades litoestratigráficas principais são reconhecidas, com direção N30-40E. A ocorrência oriental é o Complexo Granítico Três Córregos (CGTC), constituído por granitos cálcio-alcalinos e mega-enclaves. A parte central é formada pela Grupo Itaiacoca, de baixo grau metamórfico. A porção ocidental é o Complexo Granítico Cunhaporanga (CGC), também com mega-enclaves. Para W, aparece o Grupo vulcânico-sedimentar molássico Castro, do Eopaleozóico, depositado em estrutura 
de graben, discordantemente sobre o CGC. É também encontrada a Formação Furnas de arenitos devonianos, unidade basal da Bacia do Paraná nessa região. O maciço alcalino cretáceo Banhadão $\left(8 \mathrm{~km}^{2}\right)$ é intrusivo no CGTC. A parte central e setentrional do CGC, fortemente intemperizada, é coberta pela bacia hidrográfica do rio Iapó, com depósitos aluviais. Os dados foram corrigidos com filtro coseno direcional (grau 6) e apresentados como cps (contagens por segundo). As respostas de $U$ e $K$ são por vezes espúrias, não correlacionáveis com dados geológicos. A maioria das intrusões do CGC apresenta valores bastante altos de The $U$, mais baixos de CT (contagem total) e baixos de $K$, em contraste com respostas nos granitos do CGTC. Valores mais altos na CT são encontrados em alguns dos plútons mais evoluidos do CGC (como o Serra do Carambei). Os granitos do CGTC podem ser divididos em dois domínios radiométricos, um adjacente à Faixa Itaiacoca e outro mais ao E-SE, correspondendo ao Granito São Sebastião, com respostas elevadas (CT e K). Os mega-enclaves são identificados, em todos os canais, por contagens mais baixas que as dos granitos. A Faixa Itaiacoca é mostrada nos mapas com contagens baixas a moderadas (CT, Th e U). O Grupo Castro aparece com padrão radiométrico complexo, controlado por sua constituição litológica. Os arenitos Furnas mostram respostas em geral baixas (mapa TC). Os depósitos aluviais do Iapó se destacam como faixas de valores muito baixos nos mapas de Th, U e CT.

Palavras-chave: Levantamento aerogamaespectrométrico; Mapeamento geológico; Projeto Aerogeofisico Serra do Mar Sul; Complexos Graníticos Cunhaporanga e Três Córregos.

\footnotetext{
${ }^{1}$ Departamento de Geociências, Universidade Estadual de Ponta Grossa, Paraná

${ }^{2}$ Departamento de Geologia, Universidade Federal do Paraná, Curitiba, Paraná

${ }^{3}$ Departamento de Mineralogia e Geotectônica, Instituto de Geociências, Universidade de São Paulo, São Paulo, Brasil
}

\section{INTRODUCTION}

The last decades witnessed an enormous increase in the use of aerogammaspectrometric data (cf. comments in Grasty et al., 1997). Applications are not only in traditional fields such as ore prospecting and geologic mapping (e.g., Gunn, 1997), but also in studies related to urban planning and recognition of potential health hazards.

The data obtained by the Aerogeophysical Project Serra do Mar Sul (APSMS) (e. g., Silva \& Mantovani, 1994) are here used as a tool in the recognition and interpretation of geological structures in a basement area occupied mainly by the two large elongated Cunhaporanga and Três Córregos Granitic Complexes, separated by the metamorphic Itaiacoca Belt, in Paraná state, southern Brazil (Fig. 1). The main interest is to explore the presence of these large granitic formations, as well as variations within these units, to be compared with the known distribution of rock types, alteration patterns and structure.

This paper is mainly a qualitative analysis, since at the beginning of this work only the tapes with qualitative information were available, with no conversion of the data (in cps) into absolute radiometric values by a back-calibration technique (cf. Grasty et al., 1997; Misener et al., 1997).

\section{METHODOLOGY}

\section{Gammaspectrometric surveys}

The decay of radioactive elements generates alfa and beta particles and gamma rays. The first ones, with low energies, are absorbed by a few centimeters or decimeters of air, while the gamma rays can be registered up to heights of about $300 \mathrm{~m}$. The gammaray response represents at the very most the composition of soil or rock down to a depth of no more than 30 or $40 \mathrm{~cm}$ (e. g., Wilford et al., 1997; Minty, 1997, and bibliography therein). The gamma rays registered in surveys are the ones from isotopes ${ }^{214} \mathrm{Bi}$ (U decay chain), ${ }^{208} \mathrm{Tl}$ (Th decay) and ${ }^{40} \mathrm{~K}$ (K decay). The window widths used in the APSMS were as follows: total counts (TC): $1.00-2.90 \mathrm{MeV} ; \mathrm{K}$ : 1.35-1.65 MeV; U: 1.65-2.30 MeV; Th: 2.30-2.90 


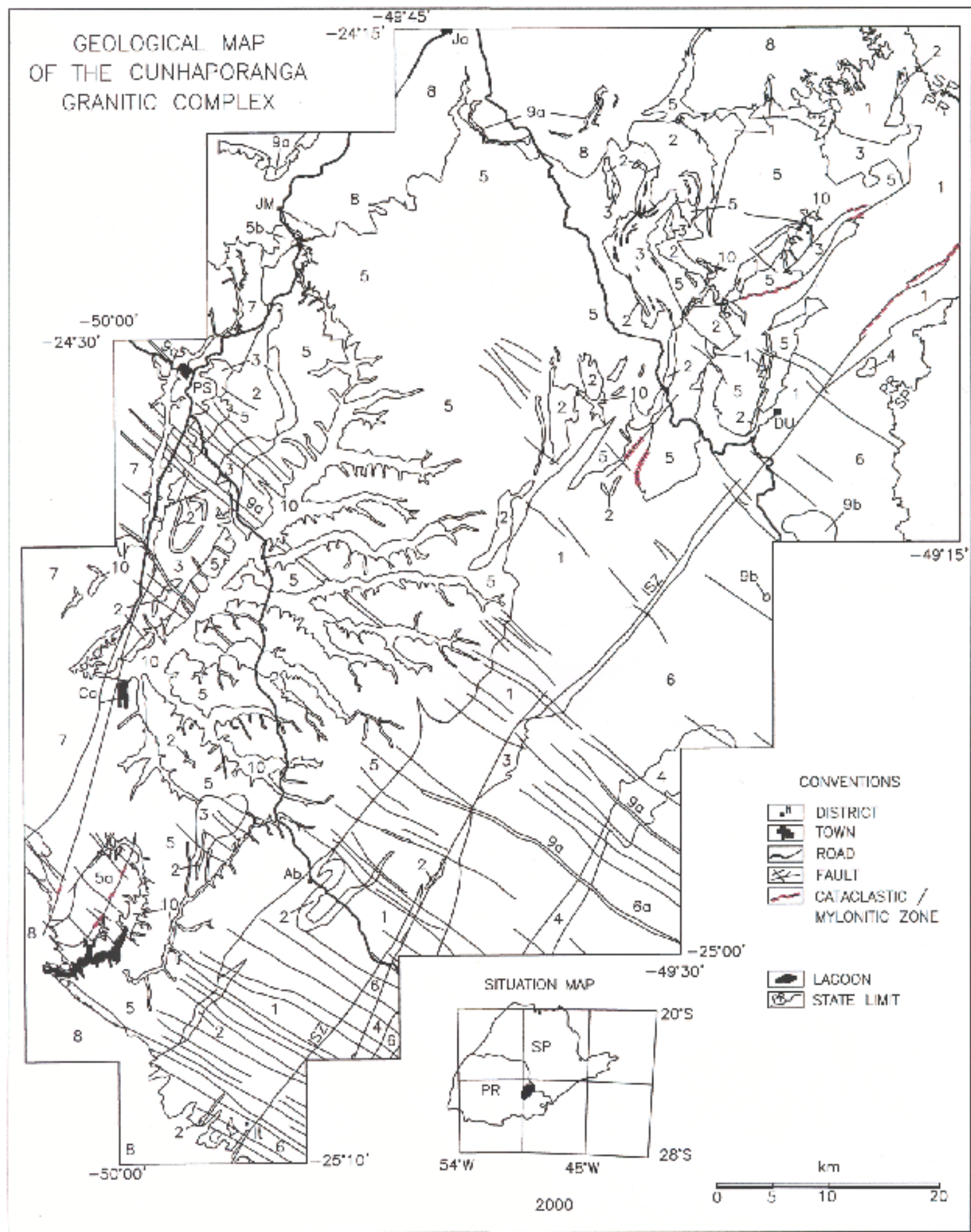

Figure 1 - Regional geologic map of the basement area in Paraná state. 1. Itaiacoca Belt; 2: Serra das Pedras Quartzite and equivalent rocks; 3: Schists and gneisses; 4: Água Clara Formation; 5: Cunhaporanga Granitic Complex, 5a: Serra do Carambeí Granite, 5b: Joaquim Murtinho Granite; 6: Três Córregos Granitic Complex, 6a: São Sebastião Granite; 7: Castro Group; 8: sedimentary rocks of the Paraná Basin; 9a: dikes of the Serra Geral Formation; 9b: Banhadão alkaline massif; 10: alluvial deposits. Compilation, from several sources, by G.B. Guimarães (1997, unpublished). ISZ: Itapirapuã shear zone. Localities: Ab: Abapã; Ca: Castro; DU: Doutor Ulysses; JM: Joaquim Murtinho; PS: Piraí do Sul. SP-PR: São Paulo-Paraná state limit.

Figura 1 - Mapa geológico regional da região do embasamento no estado de Paraná. 1. Faixa Itaiacoca; 2: Quartzito Serra das Pedras e rochas equivalentes; 3: xistos e gneisses; 4. Formação Água Clara; 5. Complexo Granítico Cunhaporanga; 5a: Granito Serra do Carambei; 5b: Granito Joaquim Murtinho; 6: Complexo Granítico Três Córregos; 6a: Granito São Sebastião; 7: Grupo Castro; 8: rochas sedimentares da Bacia do Paraná; 9a: diques da Formação Serra Geral; 9b: maciço alcalino de Banhadão; 10: depósitos aluviais. Compilação de várias fontes por G.B. Guimarães (1997, inédito). ISZ: zona de cisalhamento Itapirapuã. Localidades: Ab: Abapã; Ca: Castro; DU: Doutor Ulysses; JM: Joaquim Murtinho; PS: Pirai do Sul. SP-PR: limite estados de São Paulo e Paraná. 


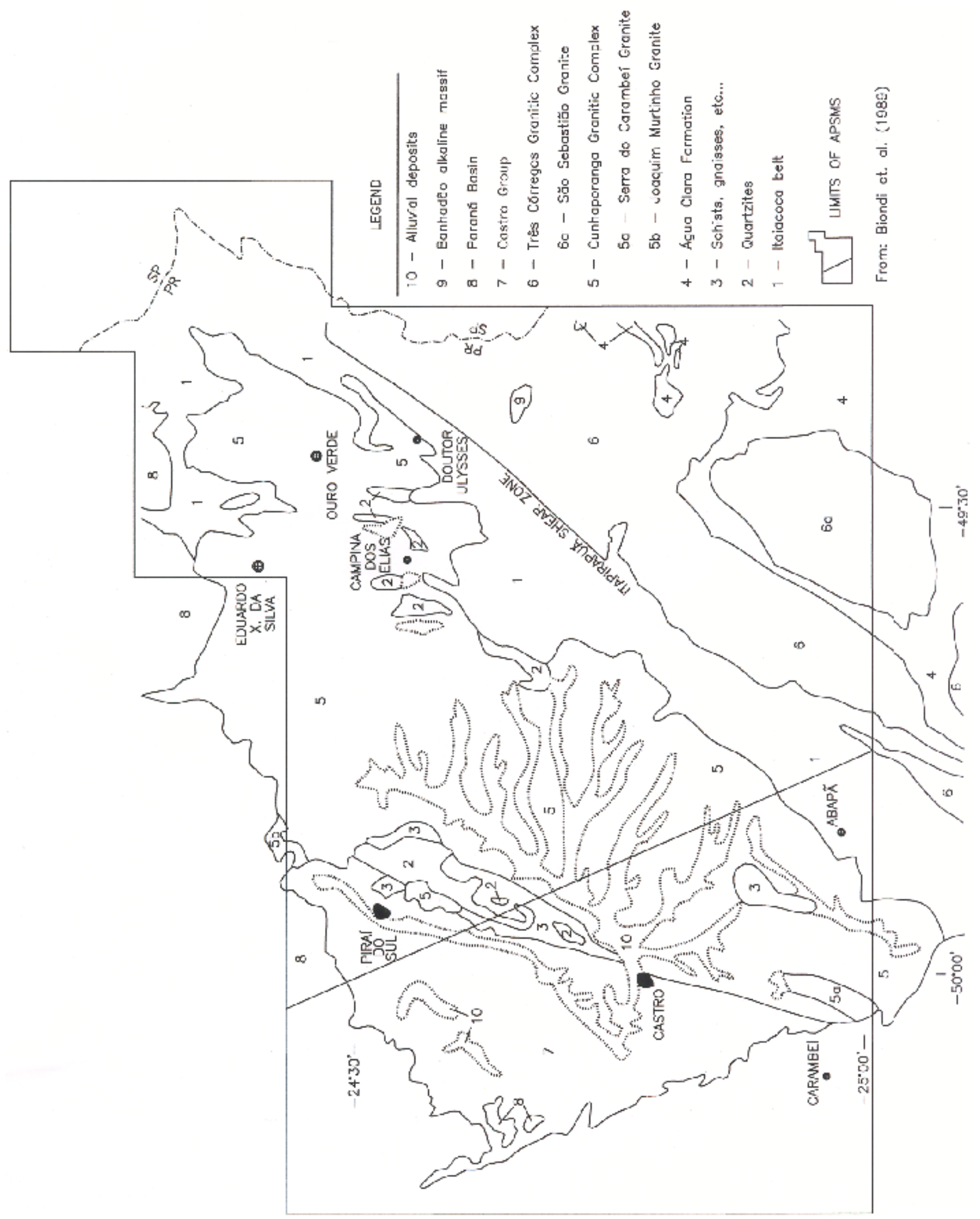

Figure 2 - Limits of the Aereogeophysical Project Serra do Mar Sul. Geologic units as in Fig. 1. NW-SE line separates the two flight areas (flights from Florianópolis, to the SW; from Curitiba, to the NE).

Figura 2 - Limites do Projeto Aerogeofísico Serra do Mar Sul. Unidades geológicas identificadas como na Fig. 1. Linha NW-SE separa as duas regiões de vôos (parte $\mathrm{SW}$, vôos de Florianópolis; parte NE, de Curitiba). 
MeV (Silva \& Mantovani, 1994), somewhat different from the ones recommended by the IAEA (1991): TC: $0.41-2.81 \mathrm{MeV}$; K: 1.37-1.57 MeV; U: 1.661.86 MeV; Th: 2.41-2.81 MeV. More information about the project can be found in GEOFOTO (1978a, 1978b).

The gamma ray emissions, under isotopic equilibrium conditions, are proportional to the contents of the emitting isotopes. The counted intensities (cps), however, depend strongly on environmental and instrumental conditions, and should be converted into elemental concentrations (eU and eTh, "equivalent" ppm abundances; $K$, percentages), by calibration with selected samples at ground level and comparison with the obtained counts (cf. Minty et al., 1997).

Uranium and $\mathrm{Th}$, and especially $\mathrm{K}$, are mobile elements that can be leached during weathering, or alternatively concentrated in regions affected by hydrothermal alteration. Alluvial and colluvial cover, as well as stagnant water, vegetation, and humidity, also have an incidence on the readings.

The $\mathrm{K}$ and Th decay sequences are relatively simple, and are mainly influenced by the behavior of the ${ }^{40} \mathrm{~K}$ and ${ }^{232} \mathrm{Th}$ isotopes. Uranium, with its two main isotopes ${ }^{235} \mathrm{U}$ and ${ }^{238} \mathrm{U}$, has a very complex decay scheme. Several of the daughter isotopes can be taken out of the original system, or added to them, leading to isotopic disequilibrium. Restauration of equilibrium conditions may take from a few days to a million years, depending on the fractionated isotope and its half life. Minty (1997) lists the main causes of isotopic disequilibrium in the $U$ chain, all related to ${ }^{238} U$ decay:

- selective leaching of ${ }^{238} \mathrm{U}$ and/or of the ${ }^{234} \mathrm{U}$ daughter isotope, in particular by adsorption in a clay matrix;

— selective leaching of ${ }^{230} \mathrm{Th}$;

- selective fractionation of ${ }^{226} \mathrm{Ra}$;

- loss to the atmosphere of the gas ${ }^{222} \mathrm{Rn}$.

Radium and $U$ can be leached selectively in varying proportions, depending on oxidation-reduction conditions in the environment. Loss of ${ }^{222} \mathrm{Rn}$ will reduce rapidly the contents of the ${ }^{214} \mathrm{~Pb}$ and ${ }^{214} \mathrm{Bi}$ daughter isotopes, and hence of ${ }^{210} \mathrm{Tl}$, which yields the most intense gamma radiation. Therefore, maps with $U$ counts have to be analysed with care. The K and Th maps, on the contrary, should register more faithfully the true contents of these elements in the surficial layer.

\section{The Aerogeophysical Project Serra do Mar Sul (APSMS)}

The APSMS is a radiometric and magnetometric airborne survey conducted in the 70's for the CPRM (Companhia de Pesquisa de Recursos Minerais, Geological Survey of Brazil). The covered area, about $50,000 \mathrm{~km}^{2}$, includes most of the crystalline basement in the states of Santa Catarina and Paraná as well as, to the $\mathrm{W}$, the outcrops of the Castro Group and the eastern limit of the Paraná Basin sediments (Fig. 2). Survey specifications were as follows (Silva \& Mantovani, 1994): flight line spacing between 750 and $1250 \mathrm{~m}$, with some local superpositions or blank strips of over $2 \mathrm{~km}$; medium flight height of $158 \mathrm{~m}$ (between 80 to about $300 \mathrm{~m}$ ); flight lines in the direction N30W, not always perpendicular to the predominant N3045E structural pattern; TC, U, Th and $\mathrm{K}$ channels as specified before. The total magnetic field was also registered.

Several shortcomings in the execution of this survey were noted: variations in the spacing of flight lines, errors in the localization of UTM coordinates (sometimes over $4 \mathrm{~km}$ ), variability in the flight height, and differences in volume in the various detector crystals used in different airplanes (Silva \& Mantovani, 1994). For practical purposes, the project has to be subdivided into two different surveys or populations, on account of topographic differences in the two used flight bases, Curitiba (altitude, $\sim 900 \mathrm{~m}$ ) and Florianópolis $(\sim 10 \mathrm{~m})$. The flight line spacing used in this survey of predominantly basement rocks allows representation on a scale not better than 1:250,000 (cf. Horsfall, 1997). The results are presented as counts per second (cps), with no conversion to ppm (eTh, eU for Th and $\mathrm{U}$ ) or \% (K). A more recent attempt (Misener et al., 1997), providing a conversion of the original cps to absolute values by a backcalibration technique (cf. Grasty et al., 1997), was not available at the time of preparation of this paper; the overall results will be checked against a planned terrestrial survey (work in progress, July of 2002) and discussed by us in a forthcoming paper. 


\section{Data acquisition and handling}

The main objective is to compare the gammaspectrometric cps results with the mapped geologic features. Data handling was carried out using the GEOSOFT ${ }^{\mathrm{TM}}$ software, on maps with scales of $1: 250,000$ and $1: 500,000$. The main geologic units are also outlined.

The uncorrected data show a distorted pattern, with artificially enhanced highs and lows along the N30W flight direction, especially visible in the $\mathrm{K}$ and $\mathrm{U}$ channels. This effect was corrected by using a directional cosine filter (degree 6) along the flight direction, cancelling or at least reducing the distortions. More precise correction procedures (e. g., Green, 1987; Minty, 1991) were not available at the time the presented cps data were processed. Even so, the obtained maps are satisfactory tools for general geologic interpretations on a qualitative basis.

\section{REGIONAL GEOLOGICAL OUTLINE}

The main geologic units in the studied area are the two large elongated Neoproterozoic Cunhaporanga and Três Córregos granitic complexes and the Itaiacoca Belt of low-grade metamorphic rocks, together with the more restricted outcrops of the Eopaleozoic volcanic-molassic Castro Group and some Phanerozoic formations of the intracratonic Paraná Basin (Fig. 1). Additional units are the small intrusive Cretaceous Banhadão alkaline massif $\left(\sim 8 \mathrm{~km}^{2}\right)$ and the prominent alluvial deposits of the Iapó river.

The well-defined Itapirapuã shear zone (ISZ; CPRM, 1977), with a general N40E direction, divides the basement into two large tectonic blocks (Soares et al., 1998; Fig. 1).

\section{The Itaiacoca Belt and related units}

The Itaiacoca Belt (e.g., Soares et al., 1987; Reis Neto, 1994; also, Itaiacoca Formation or Itaiacoca Group) shows a thick and complexly folded sequence of metamorphosed rocks, and a general N40E elongation(Fig. 1). Most geologists identify three main units, confirmed by recent mapping in the central Itaiacoca Belt (Prazeres et al., 1998). There, the basal sequence is mainly formed by whitish arkosic sandstones and vesicular meta-volcanic rocks (the Abapã Formation or Sequence of Trein et al., 1985; Lima et al., 1993). The intermediate unit is mainly dolomitic, replaced to the $\mathrm{N}$ by pelitic rocks, which constitute the third and upper unit; together, the metadolomites and metapelites constitute the Tanque Grande Formation of Lima et al. (1993). All rocks are weakly metamorphosed (lower greenschist facies) and show preserved primary structures. The whole sequence is folded by a NE/SW folding episode (folding axis), accompanied by the formation of a late axial-plane slaty cleavage with N30-45E orientation.

A similar stratigraphic division is recognized in the southern region of the Itaiacoca belt (Marini et al., 1967b; Lima et al., 1993). In the northern region, weakly metamorphosed basal arenites and arkoses pass into a middle unit of metapelites, meta-arenites and metadolomites and, finally, into the uppermost metadolomites (Soares et al., 1987; Souza, 1990).

The "Serra das Pedras Quartzite" (SPQ; cf. Fuck, 1967) crops out as a large mega-enclave in the Cunhaporanga Complex (Fig. 1), and shows mainly weathered white meta-arkoses and quartz-rich metaarenites, with interbedded kaolinitic layers (altered tuffs?). Some sheared Cunhaporanga granites also occur in this region (Guimarães, 1995), formerly mapped as "gneisses and migmatites". Similar "quartzites", possibly correlated with the SPQ, are found as smaller enclaves within the Cunhaporanga granites.

\section{The Três Córregos Granitic Complex (TCGC)}

The TCGC (Fuck, 1966; Algarte \& Kaefer, 1972) covers an area of about $3700 \mathrm{~km}^{2}$ and extends to the N into São Paulo state (Fig. 1). Its eastern contact, with low-grade metamorphic rocks of the Água Clara Formation and the Açungui Group, is intrusive. The western contact is mainly tectonic, limited by the ISZ. Main rocks are both equigranular and porphyritic calc-alkaline granites, together with migmatites, all cut by post-tectonic A-type granitic plutons of the so-called Itu granitic belt (e.g., Fuck et al., 1967; Gimenez Filho, 1993; Vlach et al., 1990). Mega-enclaves and roof pendants of the Água Clara Formation (medium grade schists, amphibolites, and 
meta-marls) and other metamorphic rocks are frequently found (Fuck et al., 1967; Gimenez Filho 1993). The batholith, interpreted as the root zone of the "Três Córregos" magmatic arc, shows Rb-Sr isochronic ages between 650 and $800 \mathrm{Ma}$, with latemagmatic intrusions appearing around 560-600 Ma (GimenezFilho, 1993; Reis Neto, 1994). More recent concordia plots indicate $\mathrm{U}-\mathrm{Pb}$ ages of $599 \pm 7.3$ and $604 \pm 3.5$ Ma for porphyritic coarse-grained Três Córregos granitic facies (Prazeres, 2000).

\section{The Cunhaporanga Granitic Complex (CGC)}

The CGC (Algarte \& Kaefer, 1972, and bibliography therein) crops out over $2500 \mathrm{~km}^{2}$, entirely within Paraná state. Contacts with the Itaiacoca belt are intrusive; to the W-NW, the complex is covered by the younger Castro Group and in part, to the N and SW, by the Furnas Formation (Fig. 1).

The granites are usually heavily weathered, and knowledge about its geology and structure is still very scant (cf. Fuck et al., 1967; Algarte \& Kaefer, 1972; CPRM, 1977; Ribas, 1981). More recent work (Guimarães, 2000) presented a preliminary geologic map outlining the most important Cunhaporanga intrusive units, also adding information about rock and mineral chemistry of the granites and metamorphic rocks. Predominant are calc-alkaline biotite $( \pm$ hornblende) granitoids. Less evolved rocks such as quartz diorites and diorites are restricted; microgranular enclaves are plentiful. Some late "epizonal" alaskitic intrusions of the so-called Itu granitoid belt are locally observed (to the $\mathrm{N}$, the Joaquim Murtinho Granite; to the S, the Serra do Carambeí massif; Pinto-Coelho \& Marini, 1986; Guimarães \& Ulbrich, 1996; Guimarães, 1995, 2000).

The CGC is considered the root zone of a Brasiliano magmatic arc (Soares, 1987; Reis Neto, 1994). Recent U-Pb concordia ages yield $567 \pm 5.8$ and $559 \pm 4.5 \mathrm{Ma}$ for Cunhaporanga porphyritic facies (Prazeres, 2000).

\section{The Castro Group}

The Eopaleozoic Castro Group (Trein \& Fuck, 1967), occupies an area of approximately $740 \mathrm{~km}^{2}$
(Fig. 1). To the W, it is covered by the Furnas sandstones; its eastern contact, with the Cunhaporanga granites, is in part tectonic. Four formations were mapped in this predominantly molassic-volcanic sequence: two basal units, a volcanic one with intermediate and acid rocks and a partly coeval sedimentary formation (arkoses, conglomerates, mudstones), and two upper units, one sedimentary with imature clastic rocks and another with acid volcanics (Moro, 1993). Rb-Sr data of rhyolites show ages around 440 to $470 \mathrm{Ma}$ (Moro, 1993). Recent $\mathrm{U}-\mathrm{Pb}$ data in zircons from rhyolites show an age of $543 \pm 12$ Ma (O.Siga Jr., Inst. Geociências, USP, 1999, pers. commun.).

\section{Sedimentary and volcanic formations of the Paraná Basin}

The Silurian-Devonian Furnas Formation is constituted by whitish medium to coarse-grained quartz sandstones, with a subordinate kaolinite matrix. There is no consensus about the depositional environment, considered either fluvial (Zalán et al., 1987) or predominantly marine (Assine, 1996). Assine (1996) recognizes three members: basal unit I, medium to coarse arenites with some conglomerates; unit II, with fine to coarse arenites and some siltstones and shales; upper unit III, again with medium to coarse arenites with conglomeratic lenses.

Dikes appear in this area with a N40-60W direction, attributed to the Lower Cretaceous Serra Geral Formation. Predominant are diabases, with some diorites and quartz monzodiorites (Marini et al., 1967a; Prazeres et al., 1998), mainly concentrated within the apex of the Ponta Grossa Arch (Fig. 1).

\section{The Banhadão alkaline massif}

The Banhadão massif (about $8 \mathrm{~km}^{2}$; Algarte \& Kaefer, 1972; Ruberti, 1984) is intrusive in the TCGC. Nepheline syenites and phlogopite melteigites are predominant; several phonolite dikes are also observed. Fenitization seems to be widespread, although masked by deep weathering of the country rocks. K-Ar ages are around 100-110 Ma (Ruberti, 1984). 


\section{Alluvial deposits}

The alluvial deposits of the Iapó river are underlain by the Castro Group and extend also over the flat northern-central region of the CGC. This region, also heavily weathered, is partly covered by water in the rainy summer months (November to March). Predominant are sandy-argilaceous and peat sediments.

\section{DISCUSSION OF THE GAMMASPECTROMETRIC DATA}

The several radiometric data are presented in Figs. 3, 4, 5 and 6 (TC, total counts, and Th, $\mathrm{U}$ and $\mathrm{K}$ counts, in cps).

\section{The Itaiacoca Belt and related units}

The radiometric maps reveal clearly the main outline of the Itaiacoca Belt (e.g., TC and K counts, Figs. 3 and 6). The areas with low to very low counts in the TC map (Fig. 3) correspond to the metacarbonatic and metapsammitic units, while medium (to locally high) values correlate with outcrops of the metapelitic formation (cf. geologic maps in CPRM, 1977; Souza, 1990; Prazeres et al., 1998). The convoluted pattern between Abapã and Socavão (TC map, Fig. 3) reflects the folds found in the first two cited units. An unusual K-rich horizon, beginning near Abapã and identified in Fig. 6 by medium to high cps, corresponds in the field to the meta-arkosic/ metavolcanic trachytic unit (Prazeres et al., 1998), referred to by Reis Neto (1994) as "feldspathic lamproites".

The SPQ is also characterized by low values in the TC, Th and U maps (Figs. 3, 4 and 5). In several geologic maps, these "quartzites" appear as a single larger occurrence (e.g., CCGP, 1966; Biondi et al., 1989), an interpretation that is in contrast with the spot-like and divided appearance of the areas with low counts in the gamma-ray maps. The fact that the unit appears in the Th and $\mathrm{K}$ maps with low counts means that no K or Th was adsorbed by the interstitial clays in the weathered surface layer (cf. Wilford et al., 1997, for discussion). Several other spots registering low to very low values, to the $\mathrm{N}$, also correspond to outcrops of "quartzites" (that is, weathered meta-arkoses and similar rocks; see Figs. 3, 4 and 5, near Ouro Verde, Campina dos Elias and E.X. da Silva).

\section{The Três Córregos Granitic Complex}

The TCGC is especially shown in the TC map and, to a lesser extent, in the K map (Figs. 3 and 6), while the Th and $U$ counts show intermediate to low values (Figs. 4 and 5). The small anomaly with higher counts in the last two maps represents the location of the alkaline Banhadão massif. The ISZ is only faintly registered in these maps as a discontinuous string (e.g., Fig. 3), so that the limit with the Itaiacoca belt is poorly shown. High to very high counts in TC and K, in a strip to the SE, determine the location within the TCGC of the more differentiated São Sebastião Granite (Figs. 3 and 6; cf. with Figs. 1 and 2). The Água Clara Formation is registered by low counts in the four radiometric maps, to the $\mathrm{W}-\mathrm{NW}$ and E-SE of the São Sebastião Granite, showing that this granite is separated from other TCGC granites (cf. especially TC and K, Figs. 3 and 6). The Água Clara rocks are also seen as a mega-enclave, opposite Abapã (low to very low counts in Figs. 3, 4 and 6).

\section{The Cunhaporanga Granitic Complex}

The rocks of the CGC are depicted in the maps as several radiometric domains, each with a uniform pattern. The TC and Th maps confirm the SE limit of the Cunhaporanga granitoid rocks, which extends as far as Abapã (Figs. 3 and 4).

The presence of granites in the central and heavily weathered Iapó drainage basin is revealed especially by high Th counts, diminishing somewhat to the $\mathrm{N}$ and $\mathrm{E}$, towards the Itaiacoca sequence (Figs. 1 and 4); weathering thus concentrated Th-bearing resistant minerals (e.g., zircon) in soils or allowed Th retention by adsorption in supergene clays and Fe-Al hidroxides (e.g., Wilford et al., 1997); the cps variations could be due to the presence of different facies of granites, and/or of metamorphic enclaves, as well as different degress of weathering. The alluvial deposits that cover the granites show low to very low Th and TC values (Figs. 3 and 4). 


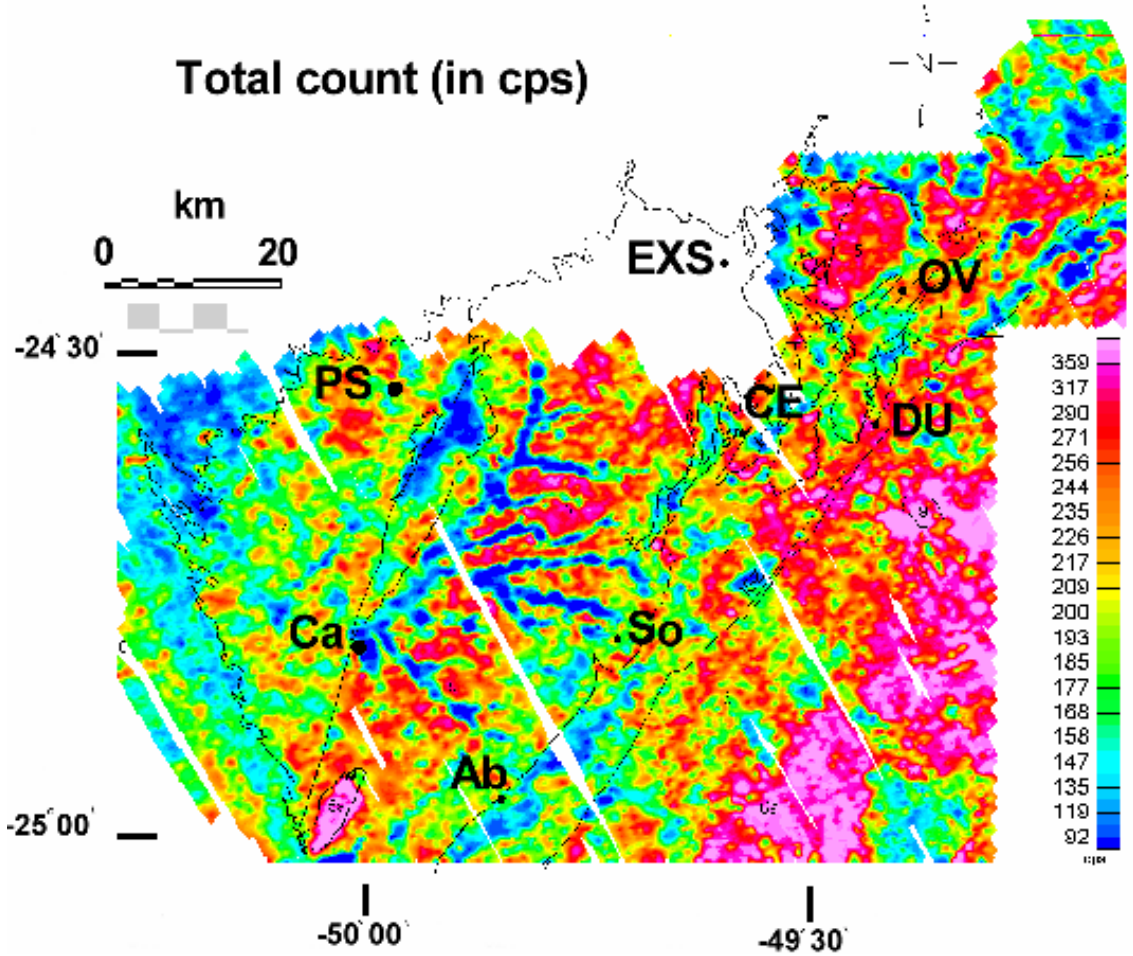

Figure 3 - Gamma-radiometric total count map (in cps). The regional geologic units are identified by outlines (simplified from Fig. 1). Localities: Ab: Abapã; Ca: Castro; CE: Campina dos Elias; DU: Doutor Ulysses; EXS: Eduardo Xavier da Silva; OV: Ouro Verde; PS: Piraí do Sul; So: Socavão.

Figura 3 - Mapa de contagem total (CT) em cps. Unidades regionais identificadas por contornos (simplificado, Fig. 1). Localidades: Ab: Abapã; Ca: Castro; CE: Campina dos Elias; DU: Doutor Ulysses; EXS: Eduardo Xavier da Silva; OV: Ouro Verde; PS: Piraí do Sul; So: Socavão.

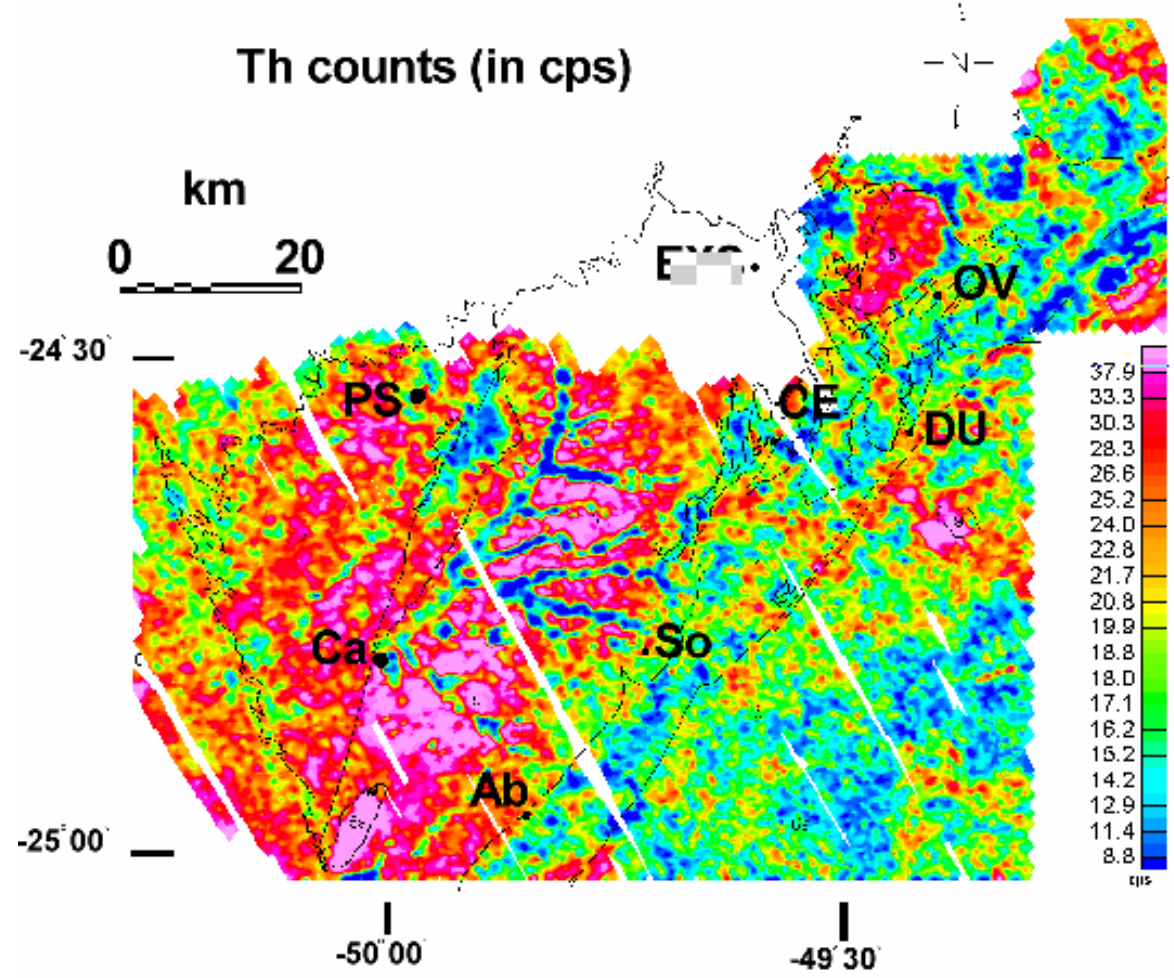

Figure 4 - Gamma-radiometric map, Th counts (in cps); cf. also legends of Figs. 1 and 3.

Figura 4 - Mapa de contagens gamaradiométricas de Th (em cps); ver também legendas das Figs. 1 e 3. 


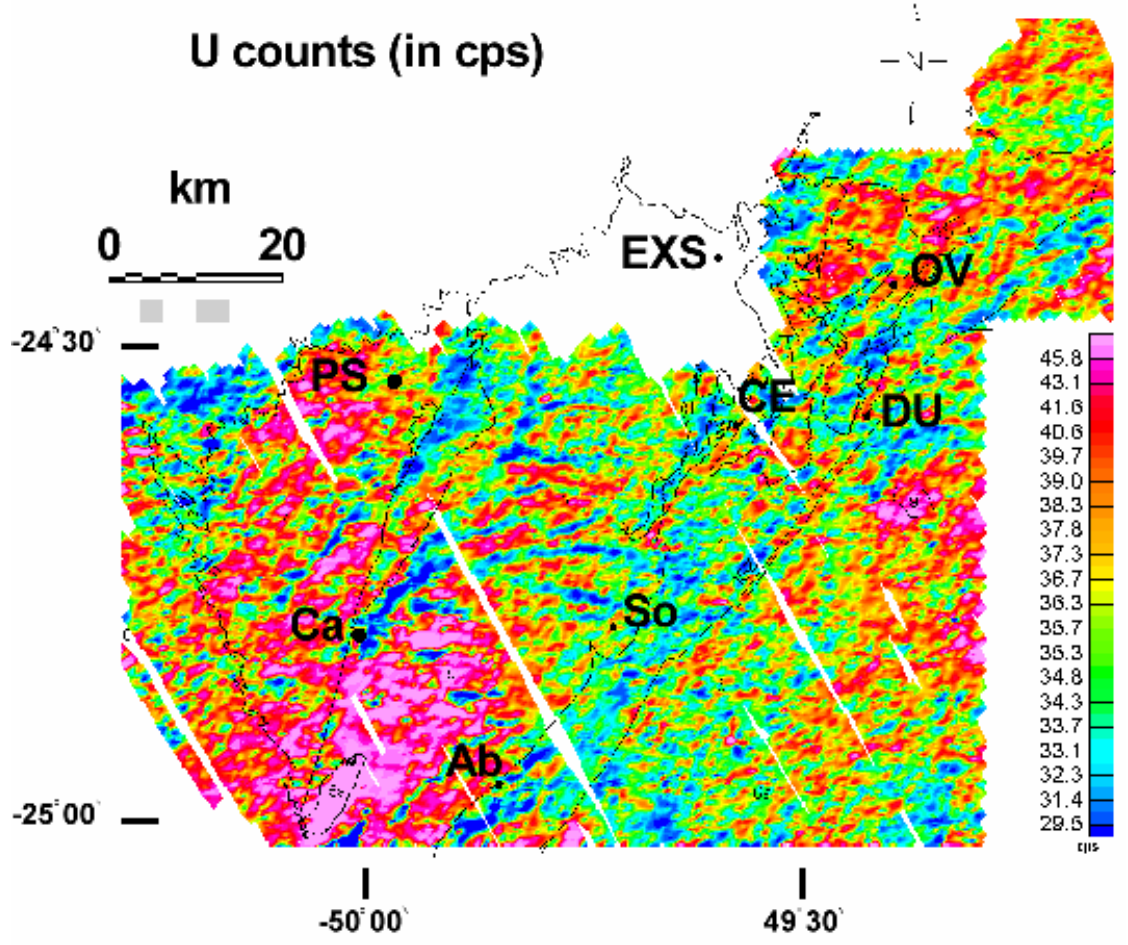

Figure 5 - Gamma-radiometric map, U counts (in cps); cf. also legends of Figs. 1 and 3.

Figura 5 - Mapa de contagens gamaradiométricas de U (em cps); ver também legendas das Figs. 1 e 3.

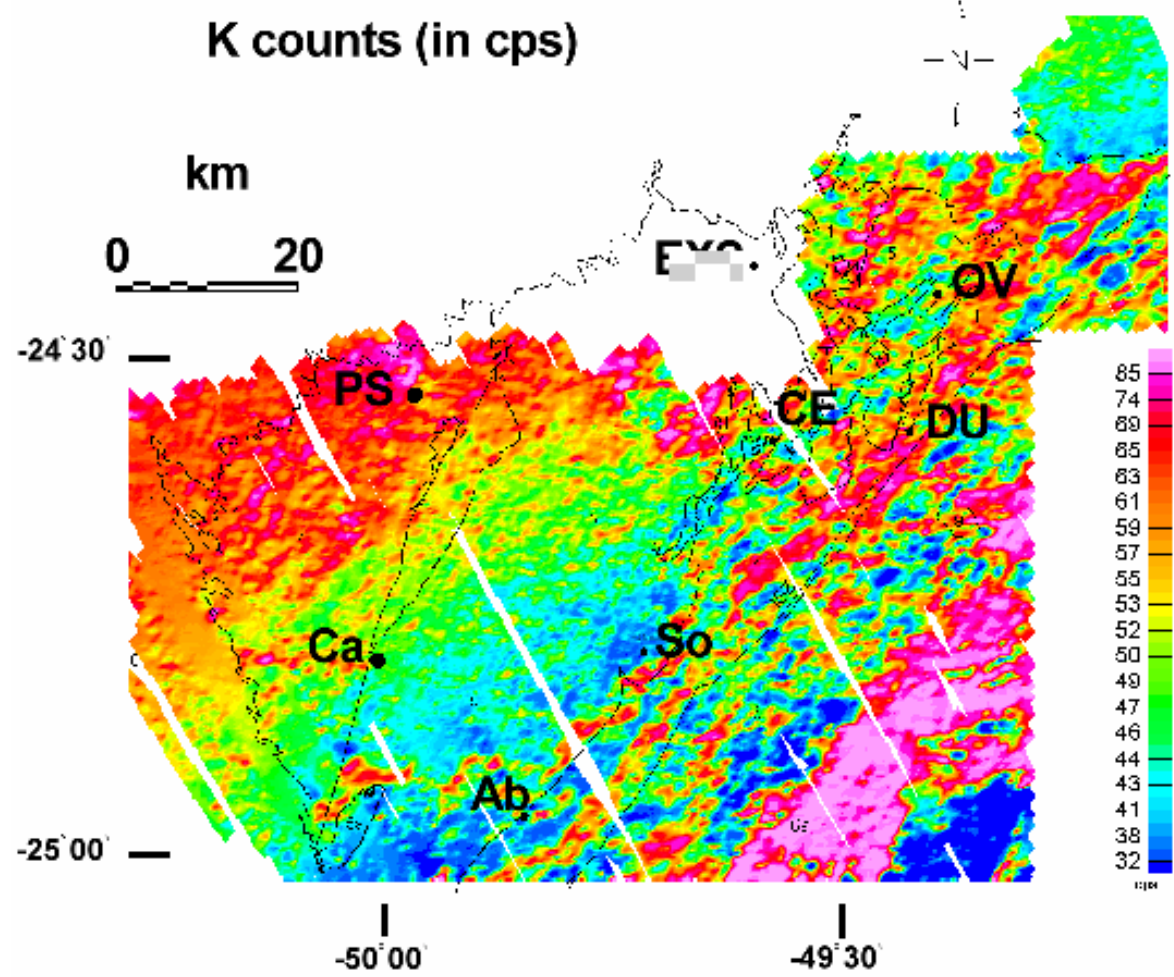

Figure 6 - Gamma-radiometric map, K counts (in cps); cf. also legends of Figs. 1 and 3.

Figura 6 - Mapa de contagens gamaradiométricas de K (em cps); ver também legendas das Figs. 1 e 3. 
The U map (Fig. 5) shows two contrasted patterns, roughly coinciding with the regions that define the two different populations in the survey (Fig. 2; Silva \& Mantovani, 1994) and are, thus, an artifact generated by the flight pattern, in no way related to geologic factors (cf. above). The region of population 1 (to the SW; Fig. 2) shows various sectors with very high $U$ values, while medium values are predominant in the other region (to the NE), with only a few spots showing high values.

In the K map (Fig. 6), the CGC is shown as an area with low to very low values, especially at its center and along a SE strip; high counts are only observed in some granitic areas to the $\mathrm{N}$, close to Campina dos Elias. This striking pattern in the $\mathrm{K}$ radiation maps, commonly detected over granites in southern and southeastern Brazil (personal experience of the authors), shows that the element was leached out of the surficial weathered blanket, a process controlled by the incipient to strong alteration of K-feldspar into kaolinite, and of biotite into hidroxides and clays (cf. Wilford et al., 1997).

To the $\mathrm{E}$ of Ouro Verde, the TC, Th and $\mathrm{U}$ maps (Figs. 3, 4 and 5; also Fig. 2) define a unique granitic oval domain $(15 \times 10 \mathrm{~km}$, largest axis oriented N30E) with high to very high values, which corresponds to granites outlined in maps (Fig. 1), possibly constituting a single unit; it is surrounded by patches with low to very low counts, indicating the presence of the Itaiacoca belt (CCGP, 1970a, 1970b; Fig. 2).

The Serra do Carambeí Granite, a region showing reasonable although scattered blocks of granites, is defined by high TC, Th and $U$ values but also by mostly low to very low K counts. Again, the contrast is strong with the expected behavior (especially in the case of this granite, rich in $\mathrm{K}$ feldspars and with $\mathrm{K}_{2} \mathrm{O}$ contents of rocks around 3-5\%; Pinto-Coelho \& Marini, 1986). In weathered areas, this pattern would reflect the effectiveness of surface alteration of Kfeldspar and biotite, very efficiently leaching out $\mathrm{K}$.

\section{Contrasted patterns in the Cunhaporanga and Três Córregos Complexes}

Th and $U$ values are usually higher in the CGC, while the TCGC is defined by higher $\mathrm{K}$ counts. This contrasted pattern reflects strong differences in weathering, much more enhanced in the Cunhaporanga granites, leaching out $\mathrm{K}$ but concentrating the residual accessory minerals (or Th and $U$ as elements) in the soils. It may also, in part, represent true differences in mineralogy (e.g., somewhat higher amounts of zircon, allanite or monazite in the CGC).

\section{The Castro Group}

The Group shows a very complex response in TC, Th and U (Figs. 3, 4 and 5), reflecting the lithologic variations. The $\mathrm{K}$ map for this area has to be interpreted with caution, since the adjacent topographic scarp of the Furnas sandstones may introduce a bias in the topographic correction, depressing (or increasing) the counted values to unrealistic figures. The Th map (Fig. 4) registers the presence of the fault that separates, to the $\mathrm{E}$, the Castro Group from the CGC. Rhyolitic domes in the Pirai do Sul region are identified by high Th counts. Some alluvial deposits are also clearly identified by low to very low values (TC, Th, and U; Figs. 3, 4 and 5). These radiometric maps help to decide among different geologic intepretations. To the SW of Castro, two irregular E-W trending domains are observed with low TC values (Fig. 3), a pattern that matches the two different horizons of porous sedimentary rocks mapped by Trein \& Fuck (1967), but is in disagreement with the single "basal sedimentary unit" proposed by Moro (1993).

\section{Sedimentary and volcanic formations of the Paraná Basin}

The limit of the Paraná Basin is defined by the Devonian Scarp, cut into Furnas sandstones, a very distinctive topographic feature. It is marked in the TC map by low to very low values, identifying the porous sedimentary rocks of the Furnas basal unit I of Assine (1996; Fig. 3); a parallel strip, with medium intensities, shows the outcrops of unit II, richer in clay minerals and with higher radiometric counts (as documented from measurements in borehole samples; Assine, 1996). The K map registers values that are incompatible with the known geology and may be a result of improper corrections (cf. Castro Group, above). The Th and U maps (Figs. 4 and 5) do not 
register clearly the limits of the Paraná Basin. The Serra Geral dikes are of limited extent and are not registered by gammaspectrometry.

\section{The Banhadão alkaline massif}

The massif is shown mainly in the Th and U maps (Figs. 4 and 5) as two separate patches or as an irregular area, in both cases however covering a surface that is much larger than the outcrops (e.g., Ruberti, 1984). Fenitization processes in the country rocks and/ or the existence of associated dikes may account for this widening of the gamma response.

\section{Alluvial deposits}

These deposits appear, especially in the TC and Th maps, as sharp sinous linear areas with very low intensity, depicting the contrast between alluvium (TC, Fig. 4) and the CGC (Th, Fig. 4; cf. also U, Fig. 5). Partial flooding of the Iapó flatlands during the rainy months, which do not dry out completely even during the dry season, will generate very low or nil responses for all radiometric channels; this may be the best explanation for the observed readings.

\section{FINAL COMMENTS AND CONCLUSIONS}

Airborne gammaspectrometric surveys in the basement region in eastern Paraná state clearly recognize most major geologic units. The folded and weakly metamorphosed Itaiacoca Belt is marked by low responses in $\mathrm{TC}$, Th, $\mathrm{U}$ and $\mathrm{K}$ maps; horizons with unusual compositions, such as a K-rich trachytic unit, are depicted in the K map.

The two large CGC and TCGC, on both sides of the Itaiacoca belt, show contrasted behavior (high Th and $\mathrm{U}$ for the $\mathrm{CGC}$; high values in the $\mathrm{K}$ map for the TCGC). The contrasts can be explained by differences in weathering, much stronger in the CGC, and in part also by variations in the contents of refractory accessory minerals, probably more concentrated in the soils overlying the Cunhaporanga granites. An enhanced pattern in some maps shows the presence of the more evolved late Serra do Carambeí (CGC) and São Sebastião (TCGC) granites. Large metasedimentary "quartzitic" enclaves in the two complexes stand out, showing low to very low counts in all maps.

The Castro Group features a complex internal stratigraphy, giving rise to an equally complex variation in the radiometric maps.

Alluvial deposits show a strongly contrasted pattern of low to very low counts especially in the $\mathrm{TC}$, Th and $\mathrm{U}$ maps, indicating the absence of radiometric elements or, alternatively, environmental influences (isotopic disequilibrium, soil humidity, flooding of alluvial plains, etc.).

\section{ACKNOWLEDGMENTS}

G.B.Guimarães gratefully acknowledges scholarships from the Brazilian agency CAPES and the State University of Ponta Grossa for granting a leave of absence for graduate studies. F.J.F. Ferreira and M. Forlin are thankful for help from the Federal University of Paraná. Field excursions, part of the lab work and the manuscript preparation were financed by grants from the São Paulo Science foundation FAPESP (Proc. 96/0783-8 and 01/072936 , to H. Ulbrich). CPRM is also thanked for the loan of the tapes with the original data of the Aerogeophysical Project Serra do Mar Sul to the Federal University of Paraná. Two unknown referees are also thanked for their comments.

\section{REFERENCES}

Algarte, J. P. \& Kaefer, L. Q., 1972. Folha de Itararé. Preliminar Geological Report. São Paulo, DNPM-CPRM, vol. I, $180 \mathrm{p}$.

Assine, M. L., 1996. Aspectos da estratigrafia das seqüências pré-carboníferas da Bacia do Paraná no Brasil. Ph.D. Thesis (unpubl.). São Paulo, Instituto de Geociências-USP, $207 \mathrm{p}$.

Biondi, J. C., Cava, L. T., \& Soares, P. C., 1989. Mapa Geológico do Estado do Paraná, 1: 650.000. Brasília, MME/DNPM/ MINEROPAR.

CCGP (Comissão da Carta Geológica do Paraná), 1966. Folha Geológica de Piraí do Sul, 1:50.000. Curitiba, CCGP.

CCGP, 1970a, Folha Geológica Jaguariaíva-Sul, 1:70.000. Curitiba, CCGP.

CCGP, 1970 b, Folha Geológica de Serra das Antas, 1:70.000. Curitiba, CCGP.

CPRM (Companhia de Pesquisa de Recursos Minerais), 1977. Projeto Leste do Paraná. 
Folha Piraí do Sul, 1:100.000. São Paulo, DNPM-CPRM-BADEP.

Fuck, R. A., 1966. Nota explicativa da Fôlha Geológica de Quero-Quero. Boletim Universidade Federal Paraná, Geologia, 19: 21 p.

Fuck, R. A., 1967. Geologia da Fôlha Abapã. Boletim Universidade Federal Paraná, Geologia, 25, 34 p.

Fuck, R. A., Marini, O. J., \& Trein, E., 1967. Contribuição ao estudo das rochas graníticas do Paraná. In: Bigarella, J. J., Salamuni, R., \& Pinto, V. M. (eds.) - 1967 - Geologia do Pré-Devoniano e intrusivas subseqüentes da porção oriental do estado do Paraná. Boletim Paranaense Geociências, 23/25: 183-219.

Geofoto S.A., 1978a, Fotogrametria, Cartografia e Aerogeofísica "Projeto Serra do Mar Sul - Fase de aquisição de dados (Levantamento aeromagnetométrico e aerogamaespectrométrico Serra do Mar entre Santa Catarina e Paraná)". MME-DNPM-CPRM, Preliminary report, unpublished.

Geofoto S.A., 1978b. Fotogrametria, cartografia e aerogeofísica, "Projeto Aerogeofísico Serra do Mar Sul - Fase de Processamento de Dados", MME-DNPM-CPRM, Final report, text and annexes, unpublished.

Gimenz Filho, A., 1993. Evolução do Complexo Granítico Três Córregos a noroeste de Apiaí, SP. M.Sc. Thesis (unpubl.). São Paulo, Instituto de Geociências, USP, 118 p.

Grasty, R. L., Smith, B. S. J., \& Minty, B. R. S., 1997. Developments in the standardization and analysis of airborne gamma ray data. In: Exploration 97, the $4^{\text {th }}$ Decennial International Conference on Mineral Exploration, Toronto, 15 p.

Green, A. A., 1987. Leveling airborne gammaradiation data using between-channel correlation information. Geophysics, 52 (11): 1557-1562.

Guimarães, G. B., 1995. O Complexo Granítico Cunhaporanga na região de Joaquim Murtinho, Piraí do Sul (PR): Caracterização faciológica das rochas granitóides. M.Sc. Thesis (unpubl.), São Paulo, Instituto de Geociências, USP, 144 p.
Guimarães, G.B., 2000. As rochas granitóides do Complexo Granítico Cunhaporanga, Paraná: aspectos geológicos, geofísicos, geoquímicos e mineralógicos. Ph.D. Thesis (unpubl.), São Paulo, Instituto de Geociências, 230 p.

Guimarães, G. B. \& Ulbrich, H. H. G. J., 1996. Redefinição e tipologia do Granito Joaquim Murtinho, Piraí do Sul (PR). In: Congr. Bras. Geol., 39, Salvador, 1996. Anais... Salvador, SBG, 6: 367-369.

Gunn, P. (ed.), 1997. Thematic issue: Airborne magnetic and radiometric surveys. AGSO Journal of Australian Geology and Geophysics, 17(2): 216 p.

Horsfall, K. R., 1997. Airborne magnetic and gamma-ray data acquisition. AGSO Journal of Australian Geology and Geophysics, 17(2): 2330.

IAEA (International Atomic Energy Agency), 1991. Airborne gamma-ray spectrometer surveying. Technical Report Series, $n^{\circ} 323$, Vienna, IAEA, $97 \mathrm{p}$.

Lima, R.E., Reis Neto, J.M., \& Monastier, M.S., 1993. Geologia da Faixa Itaiacoca/PR: estratigrafia, litologia, depósitos de talco e intrusivas associadas. In: Simpósio Sulbrasileiro de Geologia, 5, Curitiba, 1993. Excursion Guide. Curitiba, SBG.

Marini, O. J., Fuck, R. A., \& Trein, E. 1967a. Intrusivas básicas jurássico-cretácicas do primeiro planalto do Paraná. In: Bigarella, J. J., Salamuni, R., \& Pinto, V. M. (eds.) - 1967 - Geologia do Pré-Devoniano e intrusivas subseqüentes da porção oriental do estado do Paraná. Boletim Paranaense Geociências, 23/25: 307-324.

Marini, O. J., Trein, E., \& Fuck, R. A., 1967 b. O Grupo Açungui no estado do Paraná. In: Bigarella, J. J., Salamuni, R., \& Pinto, V. M. (eds.) - 1967 - Geologia do Pré-Devoniano e intrusivas subseqüentes da porção oriental do estado do Paraná. Boletim Paranaense Geociências, 23/25: 43-103.

Minty, B. R. S., 1991. Simple micro-levelling for aeromagnetic data. Exploration Geophysics, 22: 591-592.

Minty, B.R.S., 1997. Fundamentals of airborne gamma-ray spectrometry. AGSO Journal of 
Australian Geology and Geophysics, 17 (2): 3950.

Minty, B. R. S., Luyendyk, A. P. J., \& Brodie, R. C., 1997. Calibration and data processing for airborne gamma-ray spectrometry. AGSO Journal of Australian Geology and Geophysics, 17(2): 5162.

Misener, D. J., Sinclair, R., \& Mourão, L. M. F., 1997. A new Brazil radiometric database generation and application. In: Congr. Intern. Soc. Bras. Geofísica, 5, São Paulo, 1997. Expanded Abstracts... São Paulo, SBGf, vol. 1: 564.

Moro, R. de P. X. M., 1993. A Bacia ordoviciana do Grupo Castro - PR. M.Sc. Thesis (unpubl.). Rio Claro, Instituto de Geociências e Ciências Exatas, Unesp, 157 p.

Pinto-Coelho, C. V. \& Marini, O. J., 1986. Assinatura em elementos terras-raras (ETR) do Granito Serra do Carambeí (Paraná) e das rochas ígneas associadas. In: Congr. Bras. Geol., 34, Goiânia, 1986. Anais... Goiânia, SBG, 3: 13111321.

Prazeres Filho, H.J., 2000. Litogeoquímica, geocronologia (U-Pb) e geologia isotópica dos Complexos Graníticos Cunhaporanga e Três Córregos, estado do Paraná. M.Sc. Thesis, (unpubl.), Instituto de Geociências, 189 p.

Prazeres Filho, H. J., Guimarães, G. B., Basei, M. A. S., Siga JR., O., Reis Neto, J. M., Campanha, G. A. C., \& Sallun Filho, W., 1998. Mapa geológico 1:50.000 da porção centro-sul da Faixa Itaiacoca-PR. In: Congr. Bras. Geol., 40, Belo Horizonte, 1998. Anais... Belo Horizonte, SBG, 36.

Reis Neto, J. M., 1994. Faixa Itaiacoca: registro de uma colisão entre dois blocos continentais no Neoproterozóico. PhD Thesis (unpubl.), São Paulo, Instituto de Geociências-USP, 255 p.

Ribas, S. M., 1981. Reconhecimento geológico do "Complexo Granítico Cunhaporanga". Technical report (unpubl.). Curitiba, MINEROPAR, 2 volumes.

Ruberti, E., 1984. Petrologia do Maciço Alcalino de Banhadão. Ph.D. Thesis (unpubl.). São Paulo, Instituto de Geociências-USP, 248 p.
Silva, D. C. da \& Mantovani, M. S. M., 1994. Projeto aerogeofísico Serra do Mar Sul: uma abordagem semi-quantitativa. Revista Brasileira de Geociências, 24 (2): 120-127.

Soares, P. C., 1987. Seqüências tecto-sedimentares e tectônica deformadora no centro-oeste do escudo paranaense. In: Simp. Sul-Bras. Geol., 3, Curitiba, 1987. Proceedings... Curitiba, SBG, 2 : 743-771.

Soares, P. C., Stevanatto, R., \& Camargo, C. R., 1987. Geologia do noroeste da Faixa Itaiacoca Paraná. In: Simp. Sul-Bras. Geol., 3, Curitiba, 1987. Proceedings... Curitiba, SBG, 1: 245-262.

Soares, P. C., Fiori, A. P., \& Rostirolla, S. P., 1998. Organização estratigráfica e estrutural dos terrenos alóctones no Cinturão Ribeira, no vale do Ribeira (PR-SP). In: Congr. Bras. Geol. , 40, Belo Horizonte, 1998. Anais... Belo Horizonte, SBG, 41.

Souza, A., 1990. Mapa Geológico na escala 1:50.000 e esboço da evolução tectônica e sedimentar do Grupo Itaiacoca, nas folhas Barra do Chapéu e Ouro Verde - SP/PR. MSc Thesis (unpubl.), São Paulo, Instituto de Geociências, USP, 200 p.

Trein, E. \& Fuck, R. A., 1967. O Grupo Castro. In: BIGARELLA, J. J., SALAMUNI, R., \& PINTO, V. M. (eds.) - 1967 - Geologia do PréDevoniano e intrusivas subseqüentes da porção oriental do estado do Paraná. Boletim Paranaense Geociências, 23/25: 257-305.

Trein, E., Reis Neto, J. M., Biondi, J. C., \& Monastier, M. S., 1985. Revisão da Formação Itaiacoca: identificação de uma seqüência metavulcano-sedimentar em Abapã (PR). In: Simp. Reg. Geol., 5, São Paulo, 1985. Proceedings... São Paulo, SBG, 1: 169-182.

Vlach, S.R.F., Janasi, V.A., \& Vasconcellos, A.C.B.C., 1990. The Itu belt: associated calcalkaline and aluminous A-type late Brasiliano granitoids in the states of São Paulo and Paraná, southern Brazil. In: Congr. Brasil. Geol., 36, Natal, RN, 1990, Anais... Natal, SBG, 4: 1700-1711.

Wilford, J. R., Bierwirth, P. N., \& Craig, M. A., 1997. Application of airborne gamma-ray spectrometry in soil/regolith mapping and applied 
geomorphology. AGSO Journal of Australian

Geology \& Geophysics, 17(2): 201-216.

Zalán, P.V., Wolff, S., Conceição, J.C. de J., Vieira, I.S., Astolfi, M.A.M., Appi, V.T., \&
Zanotto, O.A., 1987. A divisão tripartite do Siluriano da Bacia do Paraná. Revista Brasileira de Geociências, 17: 242-252.

\section{NOTE ABOUT THE AUTHORS}

\section{Francisco José Fonseca Ferreira}

Geólogo (UFPE, 1970), especialista em geofísica aplicada (UFBA, 1974), mestre e doutor em Ciências (USP, 1982; USP, 1991), com trabalhos realizados na CPRM (1972198) e no IPT (1981-1990). Desde 1992 é professor adjunto do Departamento de Geologia da UFPR, ministrando disciplinas em Geofísica Aplicada. Publicou mais de cem trabalhos e resumos em congressos e revistas especializadas. As principais pesquisas são em geofísica aplicada ao mapeamento, exploração mineral e águas subterrâneas (e-mail: francisco.ferreira@ufpr.br).

\section{Gilson Burigo Guimarães}

Geólogo (UFPR, 1987), com especialização em geologia exploratória. É mestre (1995) e doutor (2000) pelo Instituto de Geociências da USP, com trabalhos sobre magmatismo granítico no estado do Paraná. É professor adjunto no Departamento de Geociências da Universidade Estadual de Ponta Grossa, PR, desde 1991. Seus interesses de pesquisa são mineralogia aplicada, petrologia ígnea e métodos geofísicos para prospecção e mapeamento (e-mail: gburigo@ig.com.br).

\section{Horstpeter Ulbrich}

Geólogo pela Universidade de Buenos Aires, Argentina, obteve o seu doutorado na Universidade de Califórnia, Berkeley, em 1974. É livre-docente do Instituto de Geociências da USP (1984) e professor titular do mesmo, desde 1996. Os seus interesses de pesquisa estão centrados em mineralogia e geoquímica analítica e de rochas, e em petrologia de rochas ígneas (e-mail: hulbrich@usp.br).

\section{Maximilian Forlin}

Geólogo (UFPR, 1989), com vários estágios profissionais (TBG, Promon, Nexpar/Petrobrás) e na UFPR (1994-2001), com especialização em técnicas geofísicas e de informática. Publicou uma dezena de trabalhos e resumos em congressos e revistas nacionais. É membro da Sociedade Brasileira de Geofísica. 


\section{PRIMEIROS TRABALHOS PUBLICADOS SOBRE O BRASIL NA REVISTA GEOPHYSICS}

A primeira referência sobre levantamentos geofísicos no Brasil, publicada na Revista GEOPHYSICS é de janeiro de 1936, no volume 1, número 1, que reproduzimos abaixo. Na última capa, reproduzimos a Introdução do primeiro artigo descrevendo um levantamento magnético em Santa Catarina, publicado em Outubro de 1936, vol. 1(3).

\section{REVIEWS}

Prospeccao Geophysica em São Paulo. By Imack Carvalho do Amaral and Henrique Capper Alves de Sousa. Bulletin ro of the Department of Mineral Production, Republic of Brazil, Rio de Janeiro, 1936. (In Portuguese.)

Part I deals with the magnetic instruments, methods and anomalies found in the areas of São Pedro-Xarqueada. Askania vertical and horizontal intensity magnetometers, and stationary instruments for photographic registration of diurnal and other changes, were used. Most of the anomalies were found to be related to diabase sills, lacoliths and dikes. Depth calculations by the methods of Tiberg, Haanel and Thalen did not correspond closely with depths found in wells, 6ut were of the same order of magnitude. Depth to basement rocks could not be calculated from the magnetic results, and the authors suggest the use of seismic methods. Tables showing the magnetic properties of the rocks in the area are included.

Part II deals with the theory, instruments, field procedure and results of gravitational surveys in the São Pedro area. Small Bamberg 6alances were used. Porosity and density of rocks in the area are listed. Calculations for interpretation are made on the assumption that masses have an infinite extent in one direction. Maps showing gradients, curvature values, and isogams are presented for the Sao Pedro and adjacent areas.

Part III deaIs with a magnetic reconnaissance in the vicinity of Pitanga and Pau D'Alho, where anomalies are related to diabase sills, dikes, and lacoliths, and to structura1 elevation of rocks of reIatively high permeability.

This publication of 102 pages contains little new in the way of theory. It will be of interest to those studying the geology of Brazil, and to those engaged in maguetic surveys involving intrusive and extrusive igneous rocks. Requests for the publication should be addressed to Bibliotheca do Departamento National da Produccao Mineral, Avenida Pasteur 404, Praia Vernelha, Rio de Janeiro, Brasil.

John H. Wilson 